\title{
On the population development of the introduced razor clam Ensis americanus near the island of Sylt (North Sea)
}

\author{
W. Armonies* \& K. Reise \\ Alfred-Wegener-Institut für Polar- und Meeresforschung, Wattenmeerstation Sylt, \\ D-25992 List, Germany
}

\begin{abstract}
The American razor clam Ensis americanus (= E. directus) was introduced into the eastern North Sea in the late 1970s. By larval and postlarval drifting the species rapidly extended its distribution, now ranging from the English Channel to the Kattegat. Near the island of Sylt in the eastern North Sea it has been recorded since 1979. Recruitment was rather irregular, with about six strong year-classes within two decades. Growth seems comparable with populations in its native range (Atlantic North America). Although present in the lower intertidal zone, maximum densities occurred in shallow subtidal sand with a biomass similar to that of dense beds of native cockles and mussels in the adjacent intertidal zone. Ensis americanus established in otherwise sparsely faunated sand (channels exposed to strong currents) as well as in dense infaunal assemblages (lower intertidal and subtidally). There were no significant interactions with resident species. In dense beds of razor clams, however, fine sediment particles accumulated which may have altered abundances of polychaetes. In spite of high annual variability, E. americanus has become a prominent component of the macrobenthos in shallow subtidal sands of the North Sea.
\end{abstract}

\section{INTRODUCTION}

The American razor clam Ensis directus (Conrad, 1843) is a well-known inhabitant of the lower intertidal and shallow subtidal zones along the entire US Atlantic coast between Labrador and Florida (Theroux \& Wigley, 1983). According to Van Urk (1964, 1987 ) the name Ensis directus refers to a Miocene fossil while the recent species should be properly named Ensis americanus (Binney, 1870). We prefer to use the latter name.

Ensis americanus (hereafter abbreviated as Ensis) was introduced to Europe in the late 1970s, presumably as larvae in the ballast water of a ship crossing the Atlantic (Von Cosel et al., 1982). Due to a long-lasting pelagic occurrence of larvae and byssus-drifting post-larvae, the species rapidly spread over the continental coastline of the North Sea from Denmark to northern France (Essink, 1985, 1986; Luczak et al., 1993). Recently it reached the British Isles and the west coast of Sweden (Howlett, 1990; Jansson, 1994). In the Netherlands, highest abundances were recorded in lower intertidal and shallow subtidal areas with a rather mobile sediment (Beukema \& Dekker, 1995). These areas were scarcely occupied by native fauna, while Ensis managed to overcome frequent sediment disturbance by burying both fast and deep (Swennen et al., 1985;

•E-mail: warmonies@awi-bremerhaven.de

(1) Biologische Anstalt Helgoland, Hamburg 


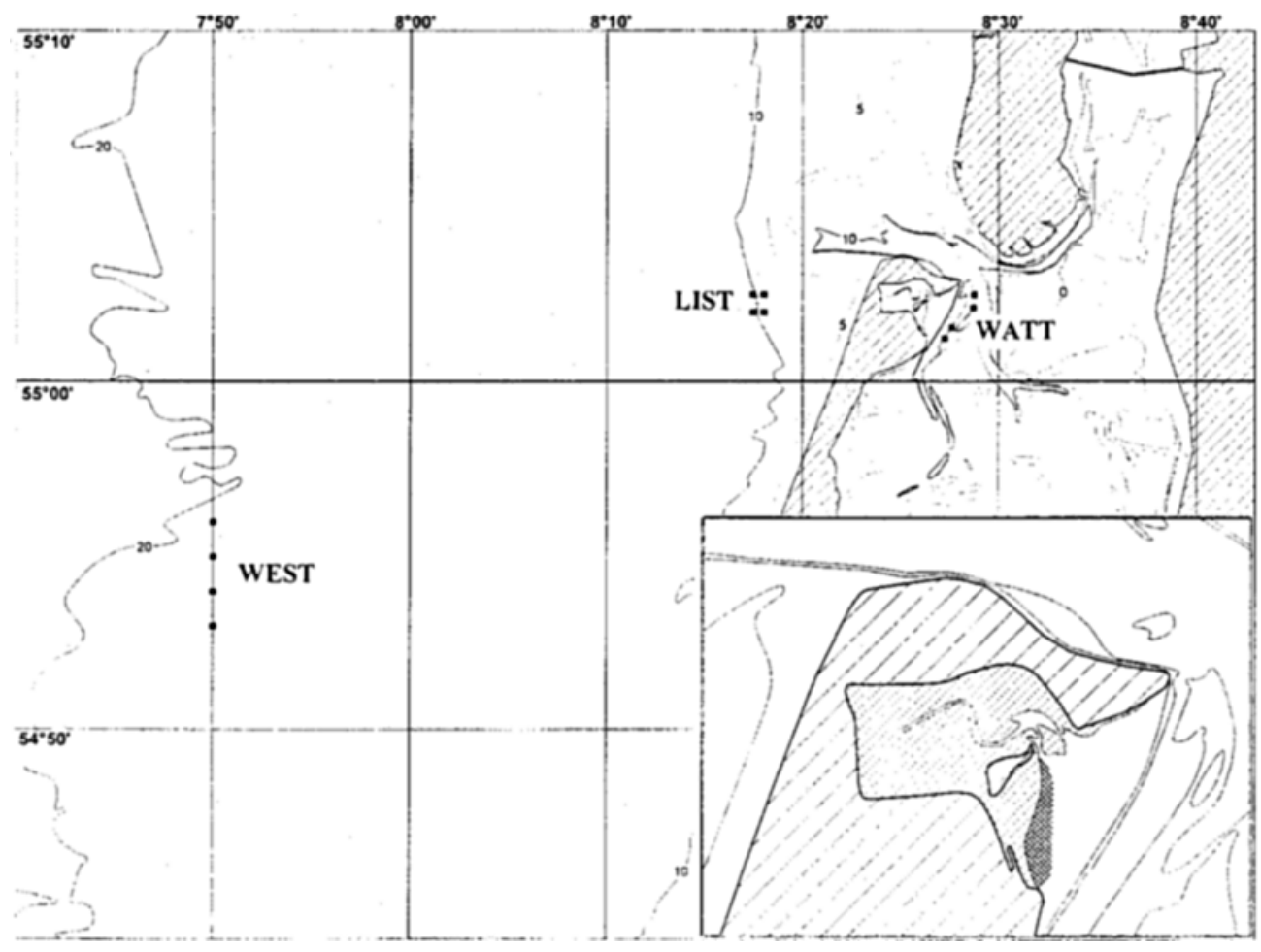

Fig. 1. Localities (West, List, Watt) near the island of Sylt regularly sampled for Ensis americanus. Inset shows the northernmost part of Sylt (hatched) with the Königshafen intertidal flats (shaded) and studied area just below spring low tide level (crosswise hatched)

Schiedek \& Zebe, 1987). Using records from the coastal waters around the island of Sylt we studied the development of the newcomer in the northern Wadden Sea, including coastal fine-sand habitats rich in other macrobenthic species. Will Ensis be able to successfully compete in habitats densely populated by other macrofauna and with abundant epibenthic predators?

\section{MATERIALS AND METHODS}

From 1992 to 1996, the development of the macrobenthic fauna was studied in three areas near the island of Sylt in the North Sea (West, water depth $20 \mathrm{~m}$; List and Watt, water depth $10 \mathrm{~m}$; see Fig. 1). The sediment is composed of fine to medium sand (median diameter of sand grains $150-200 \mu \mathrm{m}$ ). In each area four sites were sampled, $1-2 \mathrm{~km}$ apart (Fig. 1). Using a Reineck box corer, six sediment samples of $0.02 \mathrm{~m}^{2}$ were collected from each of the sites, in March and September. The sediment was sieved through $1-\mathrm{mm}^{2}$ meshes and the residue preserved in 5\% buffered formalin/seawater solution. From these samples the macrofauna was identified to the lowest possible taxonomic level, counted, and bivalves measured to the nearest millimetre. In addition to these subtidal sites we studied an area just below spring low tide level east of Sylt (Fig. 1, in- 
set). Here, 15 cores of $0.02 \mathrm{~m}^{2}$ were collected by hand in March 1993, when strong offshore winds exposed this area.

The intertidal distribution of Ensis was studied in August/September 1989 (completed by sampling a few plots in August 1990) by mapping the tidal flats of Königshafen (Fig. 1) based on a grid of $100 \times 100 \mathrm{~m}$ plots $(n=450$ plots). Every second plot (total $n=222$ ) was studied by 20 times excavating the sediment from $30 \times 30 \mathrm{~cm}$ areas with a spade. The sediment was searched by hand and the species visible to the naked eye were recorded in a presence/absence sheet. These 20 samples from each of the plots yielded a semi-quantitative estimate of species abundance (range 0-20 occurrences per plot). Since its first appearance in 1979, qualitative records on the occurrence and size of Ensis have been taken all around the island of Sylt.

\section{RESULTS}

\section{Recruitment}

Recruitment showed strong year-to-year variability. Since its first spatfall in 1979 , strong cohorts originated in 1981, 1986, 1987, 1990, and 1994 in the lower intertidal zone. In the subtidal Wadden Sea (site Watt), an outstanding recruitment occurred in 1993 when some 1900 Ensis $\mathrm{m}^{-2}$ accumulated until September (see Table 1), 57\% of which survived their first winter. With an average of 1500 recruits $\mathrm{m}^{-2}$ the same year class was successful in the subtidal North Sed (site List, see Fig. 1) as well.

\section{Abundance and biomass}

In the Königshafen intertidal, Ensis large enough to be detected with the naked eye were essentially restricted to the flats below mean tidal level (Fig. 2) and abundance increased towards low tide level. The maximum intertidal density of Ensis $\left(33 \mathrm{~m}^{-2}\right)$ was found just below spring low tide level in March 1993 (crosswise hatched area in Fig. 1). This population was composed of 0.5 - to 2.5 -year-old specimens and had a biomass of $78 \mathrm{~g}$ ash free dry weight (AFDW) $\mathrm{m}^{-2}$. This amounts to $66 \%$ of the total macrofaunal biomass at this low intertidal site.

In the subtidal, recruit abundances of up to $2000 \mathrm{~m}^{-2}$ occurred at least once in all three areas (Table 1). Peaks of biomass were associated with cohorts 1.5 or 2.5 years old and reached values as high as $667 \mathrm{~g} \mathrm{AFDW} \mathrm{m}^{-2}$ in the Wadden Sea and $250 \mathrm{~g}$ AFDW $\mathrm{m}^{-2}$ in the North Sea. No other species reached a comparable biomass at the same time; hence Ensis was the prominent species (Table 1). Within single sites, peaks of abundance and biomass even attained twice these values (maximum recorded biomass $1400 \mathrm{~g}$ AFDW $\mathrm{m}^{-2}$, which may be equivalent to some $15 \mathrm{~kg} \mathrm{FW} \mathrm{m}^{-2}$ ).

\section{Growth}

The size of Ensis varied strongly between years and sites (Table 2). Average size of 1-year-old individuals did not significantly differ between the List site west of the island and the subtidal Wadden Sea (Watt). However, 2-year-old specimens grew larger in the Wadden Sea (Table 2). In the intertidal zone, the 1979 cohort stayed unusually small 
Table 1. Abundance $\left(n \mathrm{~m}^{-2}\right)$ and biomass (g AFDW m $\mathrm{m}^{-2}$ ) of Ensis americanus in three subtidal areas near the island of Sylt, September 1992-1996. Numbers in parentheses give percentage share of Ensis biomass in macrobenthos communities. See Fig. 1 for localities

\begin{tabular}{|c|c|c|c|c|c|c|}
\hline \multirow{2}{*}{$\begin{array}{l}\text { Site } \\
\text { Year }\end{array}$} & \multicolumn{2}{|c|}{ West } & \multicolumn{2}{|c|}{ List } & \multicolumn{2}{|c|}{ Watt } \\
\hline & $\begin{array}{l}\text { Abun- } \\
\text { dance }\end{array}$ & Biomass & $\begin{array}{l}\text { Abun- } \\
\text { dance }\end{array}$ & Biomass & $\begin{array}{l}\text { Abun- } \\
\text { dance }\end{array}$ & Biomass \\
\hline 1992 & $<10$ & $<0.1(<1 \%)$ & 19 & $0.6 \quad\left(3^{(1)}\right)$ & $<10$ & $<0.1 \quad(3 \%)$ \\
\hline 1993 & $<10$ & $<0.1(<1 \%)$ & 1500 & $18.5(45 \%)$ & 1925 & $38.1(97 \%)$ \\
\hline 1994 & $<10$ & $<0.1(<1 \%)$ & 2025 & $249.9\left(93^{\prime \prime \prime}\right)$ & 1159 & $36.8(99 \%)$ \\
\hline 1995 & $<10$ & $<0.1(<1 \%)$ & 204 & $22.2(73 \%)$ & 467 & $468.8 \quad(99 \% / 1)$ \\
\hline 1996 & 1883 & $6.2(22 \%)$ & 38 & $13.7(65 \%)$ & 688 & $666.7 \quad(99 \%)$ \\
\hline
\end{tabular}

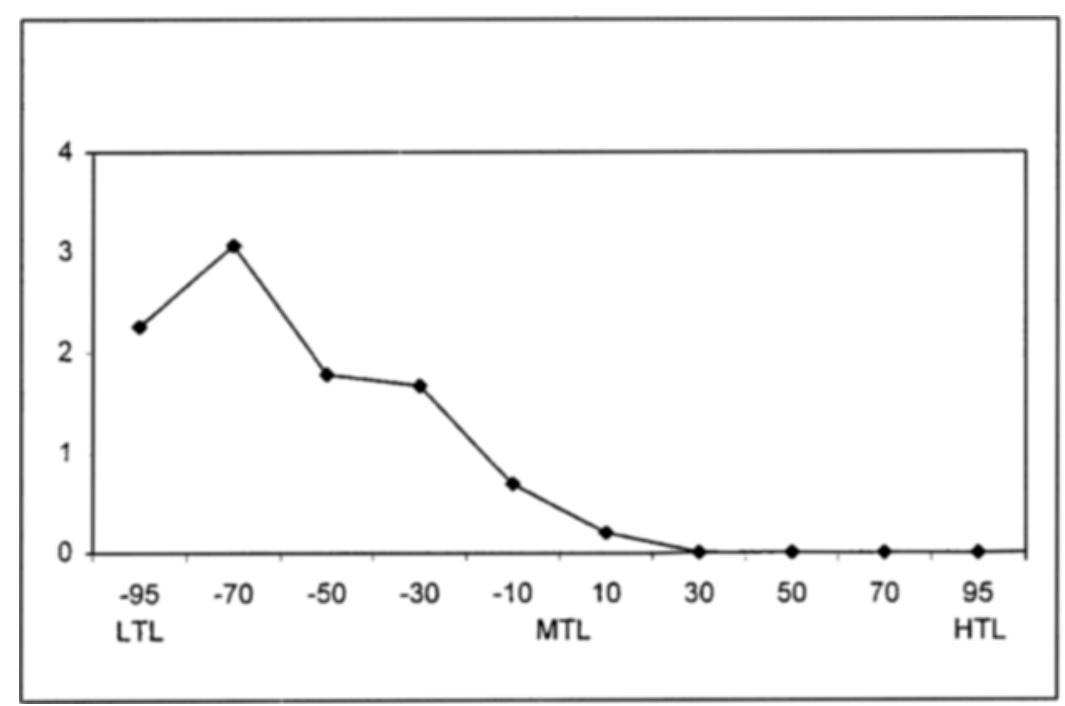

Fig. 2. Mean abundance of E. americanus in tidal levels of Königshafen (August/September 1989, August 1990). Abundance was estimated by the mean number of occurrences per studied plot (presence, range 0-20), here averaged over the plots within each height interval. The total number

of studied plots was 222. LTL, low tide level; HTL, high tide level; MTL, mean tidal level

during their first year; possibly these specimens derived from a late spatfall. During their second year, however, they achieved average size. The largest individual found had a shell length of $186 \mathrm{~mm}$ and an estimated age of 7 years. However, most cohorts disappeared as they attained an age of 2-4 years.

\section{Mass mortality}

In February 1991 and again in March 1994 we observed masses of mostly 4-year-old Ensis protruding above the sediment by about half their length in the intertidal zone (Fig. 3). Some of them rapidly re-buried when we approached, but most of them showed no reaction, even after touching. During the following weeks, these organisms died and 
Table 2. Average shell length ( $\mathrm{mm})$ of cohorts of Ensis americanus in the North Sea

\begin{tabular}{|c|c|c|c|c|c|}
\hline \multirow[t]{2}{*}{ Site } & \multicolumn{4}{|c|}{ Age } & \multirow{2}{*}{ Reference } \\
\hline & 1 year & 2 years & 3 years & 4 years & \\
\hline DK, Blåvandshuk beach & 48 & 109 & 137 & 152 & $\begin{array}{l}\text { Mühlenhardt-Siegel } \\
\text { et al., } 1983\end{array}$ \\
\hline D, Sylt & 43 & 94 & 124 & & $\begin{array}{l}\text { Mühlenhardt-Siegel } \\
\text { et al., } 1983\end{array}$ \\
\hline D, Sylt intertidal: cohort 1979 & 21 & 92 & & & This study \\
\hline D, Sylt intertidal: cohort 1990 & 43 & 97 & 127 & 133 & This study \\
\hline D. Sylt WATT & 34 & $82-92$ & & & This study \\
\hline D, Sylt LIST $\cdots \cdots$ & $26-39$ & $67-81$ & & & This study \\
\hline D. Sylt WEST & $15^{*}$ & & & & This study \\
\hline D, Langeness intertidal ${ }^{*}$ & $27-30$ & $78-84$ & & & Swennen et al., 1985 \\
\hline D, Großer Vogelsand $\cdots$ & $10-50$ & $60-105$ & & & Dörjes 1992 \\
\hline NL, lower intertidal & 64 & 126 & 144 & & Beukema \& Dekker 1995 \\
\hline F, Dunkerque & $35^{*}$ & & & & Luczak et al., 1993 \\
\hline \multicolumn{6}{|c|}{$\begin{array}{l}\text { DK, Denmark } D, \text { Germany; NL, the Netherlands; F, France } \\
\ldots \text { age } 0.5 \text { years } \\
\ldots \text { range of averages from three sites } \\
\text {.*. range of averages from three sites studied over } 10 \text { years, estimated from graph } \\
\text { range of averages from } 4 \text { years }\end{array}$} \\
\hline
\end{tabular}

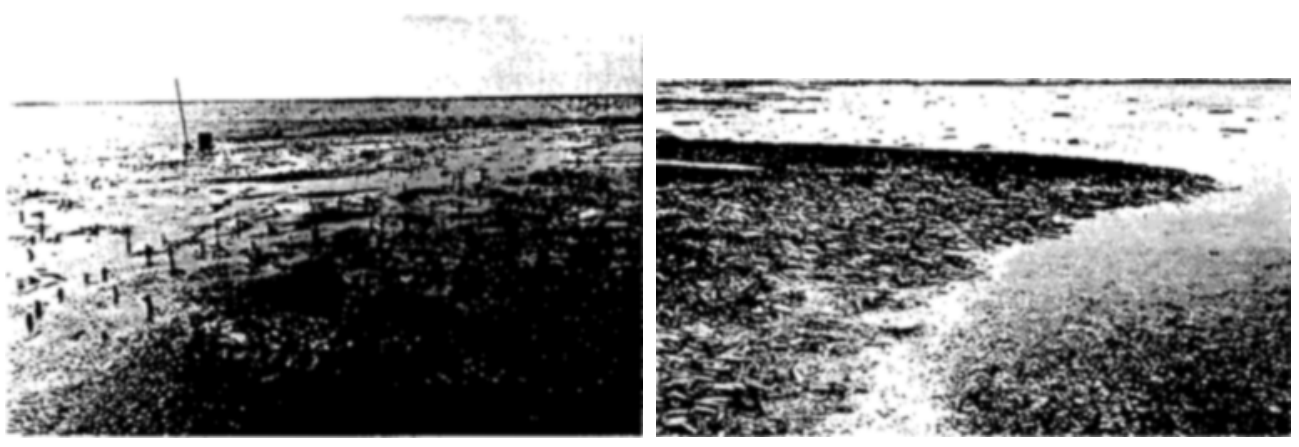

Fig. 3. Four-year old E. americanus protruding above the sediment after a cold spell in March 1994 (left) and later washed shoreward, here accumulating at a mussel bed (right) in Königshafen, island of Sylt

got washed ashore. Mass mortality also occurred in cohorts of $<1$-year-old specimens, i.e. in the lower intertidal zone of Königshafen in March 1980 and February 1982.

\section{DISCUSSION}

\section{Recruitment}

Ensis release eggs in March and April (Mühlenhardt-Siegel et al., 1983) and spatfall occurs after a planktonic phase of 2-4 weeks. However, in the northern Wadden Sea there are several periods of spatfall (Armonies, 1992, 1996). This may have caused the several 
peaks in the size distribution of single year-classes observed by Mühlenhardt-Siegel et al. (1983). In the Sylt data the first peak was always the highest (Armonies, 1992, 1996). Unpublished data on other bivalves in the Sylt area indicate that this may be a rather general pattern of reproduction.

Near the island of Sylt initial spatfall mainly occurred in the lowermost intertidal and shallow subtidal zone while byssus-drifting post-larvae moved towards deeper waters during the following weeks (Armonies, 1996). During these migrations many juveniles intermittently showed up in upper intertidal flats but did not stay there. In laboratory experiments they avoided the burrowing and defaecation activity of lugworms Arenicola marina (Dölle, 1996). Thus, less recruitment in higher than in lower parts of the intertidal zone as observed by Beukema \& Dekker (1995) is not due to a lack of potential settlers but indicates habitat selection by drifting juveniles (Armonies, 1998).

Recruitment generally showed a strong year-to-year variability (Table 1). In the Dutch intertidal zone, a strong recruitment occurred only once in 13 years (Beukema \& Dekker, 1995). Of these recruits only $4 \%$ survived their first winter. Generally, over-winter survival decreased with increasing tidal elevation. However, since juveniles up to $55 \mathrm{~mm}$ in length have been observed drifting in the water column (Essink, 1985, and references therein) the specimens might in part have left the upper intertidal sites, resulting in skewed estimates of local survival. Similar winter migrations also occur in other bivalves like Macoma balthica, leading these organisms from the high intertidal towards lower tidal elevations (Beukema, 1993).

A low over-winter survival $(1-7 \%)$ was also reported for subtidal populations in most of the years, while Mühlenhardt-Siegel et al. (1983) reported on a single year with a survival as high as $55 \%$. The situation is similar in the Sylt area where a high recruitment and a high over-winter survival were only observed in 1993/1994 (Watt and List sites). However, the burrowing capacity of Ensis might strongly skew abundance estimates as well as derived parameters like mortality. Broken individuals in our samples indicate that penetration depth of our box corer was insufficient for the vertical burrowing capabilities even of only 1-year-old Ensis. As larger individuals are even deeper burrowers (Swennen et al., 1985) abundance of older year classes may mostly be underestimated. In addition, because of seasonal differences in bioturbation activity and spatial differences in sediment composition, average penetration depth of our box corer varied with the season and the sites. This results in corresponding differences in sampling efficiency of the deep-dwelling fauna.

Both a high recruitment in few years only and a low average winter survival are rather common among Wadden Sea bivalves (Beukema, 1990, and references therein). However, a high mortality, particularly of the youngest size class, by crab predation in late summer is also quite common in the Wadden Sea. Therefore the timing of sample collection is crucial for discriminating between late summer mortality and over-winter survival in a strict sense.

\section{Abundance and biomass}

In intertidal populations abundance was found to correlate negatively with increasing tidal height. Beukema \& Dekker (1995) reported a maximum density of $144 \mathrm{~m}^{-2}$ (recruits) and a maximum biomass of $17.4 \mathrm{~g} \mathrm{AFDW} \mathrm{m}^{-2}$ (in a cohort of 2.5 -year-old speci- 
mens). The maximum density found in the Sylt intertidal zone was lower, but since the Sylt population was composed of specimens up to 3.5 years old, biomass was higher (78 $\mathrm{g} \mathrm{AFDW} \mathrm{m}^{-2}$ ).

Subtidal populations seem to prefer a water depth $<18 \mathrm{~m}$ (see below) while the maximum recorded locality in the North Sea was as deep as $26 \mathrm{~m}$ (Mühlenhardt-Siegel et al., 1983). Shortly after spatfall these authors found an abundance of 440 recruits $\mathrm{m}^{-2}$ in the entire area studied and a local maximum of $15440 \mathrm{~m}^{-2}$. These figures surpass the respective intertidal values by an order of magnitude. Due to low survival, however, biomass ( $24 \mathrm{~g} \mathrm{AFDW} \mathrm{m}^{-2}$ ) did not exceed intertidal values. In the subtidal near the island of Sylt, recruit abundances of some $2000 \mathrm{~m}^{-2}$ occurred in all three areas during one or several years. Peaks of biomass were associated with cohorts 1.5 or 2.5 years old and reached values as high as $667 \mathrm{~g} \mathrm{AFDW} \mathrm{m}^{-2}$ (Table 1). These values are similar to cockle (Cerastoderma edule) or mussel (Mytilus edulis) beds in the same area (Reise et al., 1994; Reise \& Lackschewitz, 1998).

\section{Growth}

In the intertidal zone, growth of juvenile Ensis correlated negatively with tidal elevation (Beukema \& Dekker, 1995). However, this does not mean that growth was still faster in subtidal habitats (see Table 2). Since the lowest growth in the subtidal was found in the West site with an average water depth of $20 \mathrm{~m}$, optimum growth conditions are expected to occur somewhere between 0 and $20 \mathrm{~m}$ depth in the North Sea. However, at the List site (depth $10 \mathrm{~m}$ ) the size of 1-year-old specimens varied strongly between years indicating that other factors than depth and latitude influence growth as well. Presumably, food and temperature will affect growth in Ensis in the same strong way as is the case in other bivalves of the Wadden Sea. As Ensis occur down to $100-\mathrm{m}$ depth along the US Atlantic coast (Theroux \& Wigley, 1983) it should be able to occupy the entire German Bight in the North Sea. However, the water column in this area is frequently density stratified in summer, with a reduced oxygen concentration in the bottom water layer (Hickel et al., 1989). Therefore the 'limited tolerance to hypoxia' noted by Schiedek \& Zebe (1987) might restrict Ensis to the shallow coastal zones without a thermohaline stratification.

The maximum shell-length so far reported from European populations is $16-17 \mathrm{~cm}$ (Beukema \& Dekker, 1995). The largest individual found in the Sylt area $(18.6 \mathrm{~cm}$, 7 years old) does not greatly increase this range. Apart from exceptions like this, the average age of adult Ensis populations in the North Sea seems to be in the range 24 years. This conclusion is also supported by shell material found washed ashore.

\section{Mass mortality}

Conspicuous events of mass mortality, mainly in late winter and early spring, accompanied the invasion of E. americanus into the North Sea from its very beginning (Mühlenhardt-Siegel et al., 1983). These authors suspected diseases, parasitism, lack of food in high-abundance areas, and energy depletion after spawning as potential causes. Lauckner (personal communucation), however, found no parasites or signs of diseases. A lack of food is also not a very convincing hypothesis because in winter en- 
ergy demand is usually low while POC (particulate organic carbon) attains its annual maximum. On the other hand, Ensis seems to be unaffected by the summer minimum in phytoplankton biomass. Energy depletion after spawning might be a possible cause for mass mortality of older year-classes in early spring but is an unlikely explanation for mortality of specimens $<1$ year old.

Two other possible causes may be added here. First, the European Ensis population might have derived from an American population at the southern limit of its distributional range which may not be adapted to low winter temperatures. Second, the original American habitats of the invaders are expected to be less affected by winter storms because prevailing westerly winds drive the waves in an offshore direction on the US Atlantic coast but in an onshore direction in the eastern part of the North Sea. As a result, the probability of being washed out of the sediment may be much higher in the European habitats than in the American ones. It is an open question, however, whether Ensis retain their fabulous burying capabilities once the ambient temperature approaches the freezing point. Thus we speculate that a combination of frequent sediment disturbance and a generally low activity in winter may be an explanation for the events of mass mortality.

\section{Effects on resident communities}

While E. americanus was mostly found in lower intertidal and shallow subtidal sandy sediments that are relatively exposed to wave action and poor in macrobenthos (Beukema \& Dekker, 1995) it also occurred in a species-rich fine-sand Macoma balthica - Tellina fabula community near Sylt (List site, water depth $10 \mathrm{~m}$ ). In this area there was only a single significant negative correlation with abundance of another bivalve (within sites, between years), viz. between the abundance of Ensis and cockles Cerastoderma edule. The latter species had an exceptionally good recruitment in 1996; then, there were almost no recruits in Ensis (Fig. 4). Positive correlations between Ensis and other infaunal species, on the other hand, were numerous and mostly seem to mirror a common response to winter temperature. Thus, there is no convincing evidence for quantitatively important interactions of the newcomer with the resident fauna and we conclude that Ensis was not competitively displaced into mobile sands. In fact, its niche in European waters seems to match the distribution along the US Atlantic coast. Since it thrives southward to Florida and down to a depth of $100 \mathrm{~m}$ (Theroux \& Wigley, 1983) further expanding of its distributional range in Europe is expected.

Dense aggregates of Ensis may take some 5-10\% of the superficial sediment volume that is then no longer available to other species. In fact, the mean of abundance of small polychaetes was decreased by some $10 \%$ in dense Ensis beds compared to neighbouring sites with a low Ensis abundance (due to small-scale spatial patchiness, however, this is statistically not significant, $p>0.1$ ). Furthermore, adding a high number of large filter feeders to a community will decrease the amount of food for other filter feeders. This may be important in the case of food limitation. Eutrophication during the past decades coincided with increases both in primary and secondary production (Beukema, 1991). This indicates that at least some parts of the coastal zone of the North Sea may indeed be food-limited, though nowadays at a relatively high level. Thus Ensis may decrease the stocks of other filter feeders such as cockles and mussels which might be- 


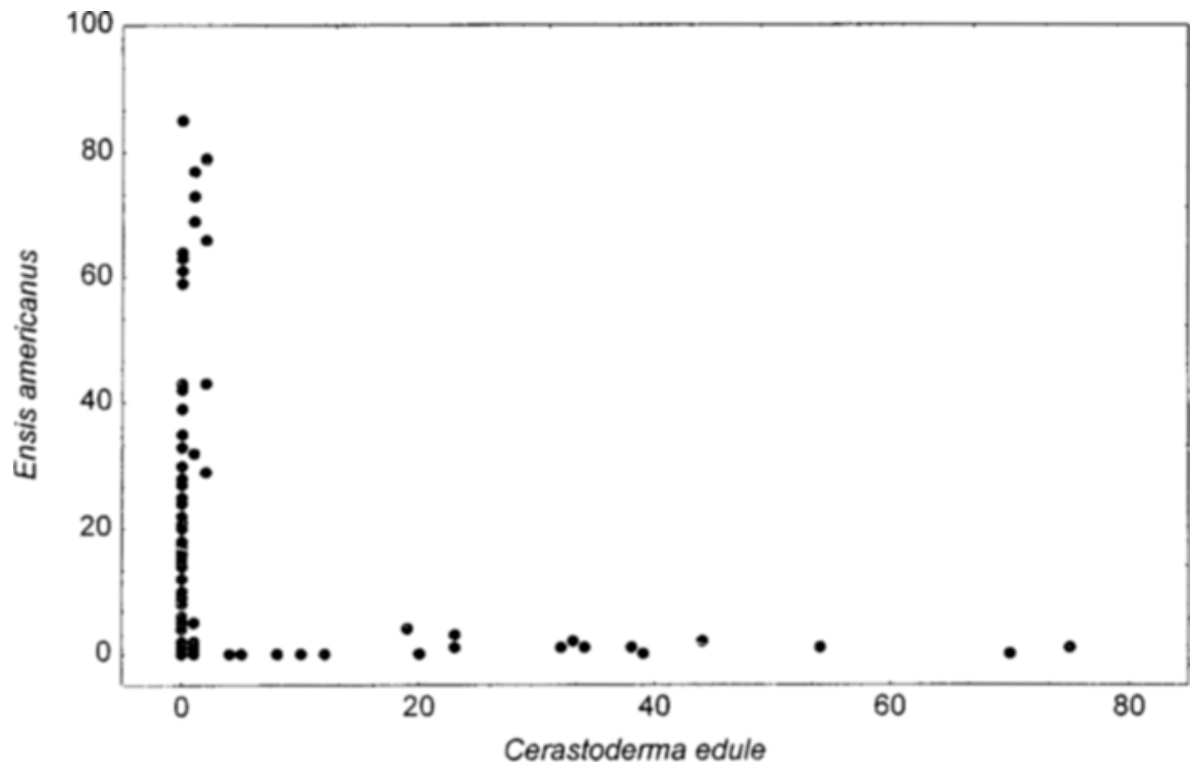

Fig. 4. Correlation between the abundances ( $n$ per box core of $0.02 \mathrm{~m}^{2}$ ) of E. americanus and Cerastoderma edule in subtidal fine sand (List site, water depth $10 \mathrm{~m} ; 24$ box cores per year collected in September, 1992-1996. Cerastoderma edule abundances $\geq 5$ all come from year 1996

come particularly important as nutrient levels are managed to decrease to a more natural (pre-industrial) level.

At the Watt site we observed that the sediment containing dense aggregates of Ensis tended to become enriched with faecal material. Sediment disturbance and megaripple migration during storm tides removed this material from the top few centimeters of sediment but it was retained in deeper sediment layers. Although this is a mere correlation and it is not known whether this material was released by Ensis, within or above the sediment, or only accumulated in Ensis beds, changes in the habitat may be expected. Sediment enriched with faecal material will have different mechanical properties, particularly concerning erodibility. This may be why at one site the percentage of very fine sand (particles $<0.125 \mathrm{~mm}$ ) increased from an average of $5 \%$ in 1992 to some $15 \%$ in 1996 . During the same period the sediment package became denser, as indicated by decreasing penetration depth of our box-corer. Therefore, the fauna is expected to change as well, in the long run. We have already observed a tendency for change in three polychaetes. Magelona mirabilis decreased $\left(104 \rightarrow 4 \mathrm{~m}^{-2}\right)$ while there were increases in Capitella capitata $(0 \rightarrow 192)$ and Capitella minima $\left(0 \rightarrow 102 \mathrm{~m}^{-2}\right)$ in these Ensis beds. Thus Ensis might not only enrich the formerly less populated mobile sands by it own presence, but also indirectly change the associated communities towards a higher diversity.

\section{LITERATURE CITED}

Armonies, W., 1992. Migratory rhythms of drifting juvenile molluscs in tidal waters of the Wadden Sea. - Mar. Ecol. Prog. Ser. 83, 197-206. 
Armonies, W., 1996. Changes in distribution patterns of 0-group bivalves in the Wadden Sea: byssus-drifting releases juveniles from the constraints of hydrography, - J. Sea Res. 35, 323-334.

Armonies, W., 1998. Driftendes Benthos im Wattenmeer: Spielball der Gezeitenströmungen? In: Ökosystem Wattenmeer: Austausch-, Transport- und Stoffumwandlungsprozesse. Ed. by C. Gätje \& K. Reise. Springer, Berlin Heidelberg, New York 473-498.

Beukema, J. J., 1990. Expected effects of changes in winter temperatures on benthic animals living in soft sediments in coastal North Sea areas. In: Expected effects of climatic change on marine coastal ecosystems. Ed. by J. J. Beukema, W. J. Wolff \& J. J. W. M. Brouns. Kluwer, Dordrecht, 83-92.

Beukema, J. J., 1991. Changes in composition of bottom fauna of a tidal-flat area during a period of eutrophication. - Mar. Biol. 111, 293-301.

Beukema, J. J., 1993. Successive changes in distribution patterns as an adaptive strategy in the bivalve Macoma balthica (L.) in the Wadden Sea. - Helgoländer Meeresunters. 47, 287-304.

Beukema, J. J. \& Dekker, R., 1995. Dynamics and growth of a recent invader into European coastal waters: the American razor clam, Ensis directus. - J. Mar. Biol. Assoc. UK 75, 351-362.

Dölle, M., 1996. Populationsstruktur der eingeschleppten Schwertmuschel Ensis americanus im Seegebiet von Sylt und Experimente zu interspezifischen Wechselbeziehungen. Diplomarbeit, Univ. Hamburg, $67 \mathrm{pp}$.

Dörjes, J., 1992. Die amerikanische Schwertmuschel Ensis directus (Conrad) in der Deutschen Bucht. III. Langzeitentwicklung nach 10 Jahren. - Senckenb. Marit. 22, 29-35.

Essink, K., 1985. On the occurrence of the American jack-knife clam Ensis directus (Conrad, 1843) (Bivalvia, Cultellidae) in the Dutch Wadden Sea. - Basteria 49, 73-80.

Essink, K., 1986. Note on the distribution of the American jack-knife clam Ensis directus (Conrad, 1843 ) in N.W. Europe (Bivalvia, Cultellidae). - Basteria 50, 33-34.

Hickel, W., Bauernfeind, E., Niermann, U. \& Westernhagen, H. v., 1989. Oxygen deficiency in the south-eastern North Sea: sources and biological effects. - Ber. Biol. Anstalt Helgoland 4, 1-148.

Howlett, D. J., 1990. The arrival in Britain of Ensis americanus. - Conchol. News 114, 301-302.

Jansson, K, 1994. Alien species in the marine environment, introductions to the Baltic Sed and the Swedish west coast. - Swedish Environmental Protection Agency, Sond, Sweden, 68 pp.

Luczak, C., Dewarumez, J.-M. \& Essink, K., 1993. First record of the American jack knife clam Ensis directus on the French coast of the North Sea. - J. Mar. Biol. Assoc. 73, 233-235.

Mühlenhardt-Siegel, U., Dörjes, J. \& von Cosel, R., 1983. Die amerikanische Schwertmuschel Ensis directus (Conrad) in der Deutschen Bucht. Il. Populationsdynamik. - Senckenb. Marit. 15, 93-110.

Reise, K., Herre, E. \& Sturm, M., 1994. Biomass and abundance of macrofauna in intertidal sediments of Königshafen in the northern Wadden Sea. - Helgoländer Meeresunters. 48, 201-215.

Reise, K. \& Lackschewitz, D., 1998. Benthos des Wattenmeeres zwischen Sylt und Rømø. In: Ökosystem Wattenmeer - Austausch-, Transport und Stoffumwandlungsprozesse. Ed. by C. Gätje \& K. Reise. Springer, Berlin Heidelberg New York, 55-64.

Schiedek, D. \& Zebe, E., 1987. Functional and environmental anaerobiosis in the razor clam Ensis directus (Mollusca: Bivalvia). - Mar. Biol. 94, 31-37.

Swennen, C., Leopold, M. F. \& Stock, M., 1985. Notes on growth and behaviour of the American razor clam Ensis directus in the Wadden Sea and the predation on it by birds. - Helgoländer Meeresunters. 39, 255-261.

Theroux, R. B. \& Wigley, R. L., 1983. Distribution and abundance of east coast bivalve molluscs based on specimens in the National Marine Fisheries Service Woods Hole collection. - NOAA Tech. Rep. NMFS SSRF-768.

Van Urk, R. M., 1964. The genus Ensis in Europe. - Basteria 28, 13-44.

Van Urk, R. M., 1987. Ensis americanus (Binney) (syn. E. directus auct. non Conrad) a recent introduction from Atlantic North-America. - J. Conchol. 32, 329-333.

Von Cosel, R., Dörjes, J. \& Mühlenhardt-Siegel, U., 1982. Die amerikanische Schwertmuschel Ensis directus (Conrad) in der Deutschen Bucht. I. Zoogeographie und Taxonomie im Vergleich mit den einheimischen Schwertmuschel-Arten. - Senckenb. Marit. 14, 147-173. 